\title{
A Convenient Synthesis of 4-Thio-D-galactofuranose
}

\author{
Oscar Varela, Daniel Cicero, and Rosa M. de Lederkremer* \\ Departamento de Quimica Orgânica, Facultad de Ciencias Exactas y Naturales, Universidad de Buenos Aires, \\ Ciudad Universitaria, Pabellön II, 1428, Buenos Aires, Argentina
}

Received August 30, 1988

\begin{abstract}
The synthesis of 4-thio-D-galactofuranose (15) and derivatives, starting from methyl $\alpha$-D-glucopyranoside (1), is described. Esterification of 1 with $N$-benzoylimidazole afforded regioselectively methyl 2,3,6-tri- $O$-benzoyl$\alpha$-D-glucopyranoside (2c). Further sulfonylation of HO-4 of 2c gave methyl 2,3,6-tri-O-benzoyl-4-O-( $p$-tolylsulfonyl)- $\alpha$-D-glucopyranoside (2e) or methyl 2,3,6-tri- $O$-benzoyl-4- $O$-[( $p$-bromophenyl)sulfonyl]- $\alpha$-D-glucopyranoside (2f). Nucleophilic substitution of the sulfonyloxy group by thiocyanate led to methyl 2,3,6-tri-O-benzoyl-4deoxy-4-thiocyano- $\alpha$-D-galactopyranoside (3). This reaction allowed the simultaneous introduction of a group precursor of thiol and the inversion of the configuration at $\mathrm{C}-4$. Compound 3 was reduced to methyl 4-Sacetyl-2,3,6-tri- $O$-benzoyl-4-thio- $\alpha$-D-galactopyranoside (4a) or methyl 2,3,6-tri- $O$-benzoyl-4-thio- $\alpha$-D-galactopyranoside (4b). The latter was debenzoylated to give methyl 4 -thio- $\alpha$-D-galactopyranoside (5). This product was also obtained by alkaline methanolysis of 3 . Ring contraction was achieved by acetolysis of 5 , which produced 1,2,3,5,6-penta- $O$-acetyl-4-thio- $\alpha$-D-galactofuranose (10) and its $\beta$-anomer (11) as the main products. The product distribution in the acetolysis reaction of 4 -thiopyranose derivatives would depend on the stability of the ionic intermediates involved. O-Deacetylation of 10 led to 4-thio-D-galactofuranose (15).
\end{abstract}

\section{Introduction}

Thio sugars exhibit a variety of interesting biological properties. For example, they could act as antimetabolites by inhibiting certain enzymes that require the normal sugar derivative in an essential metabolic step. ${ }^{1}$ Furthermore, sugars having sulfur in the ring have been examined as possible therapeutic agents. Thus, 5-thio-Dglucopyranose has been found ${ }^{1}$ to inhibit the transport of D-glucose and the release of insulin. The substance also kills tumor cells selectively under hypoxic conditions ${ }^{2}$ and causes reversible inhibition of sperm-cell development in mice, without displaying acute toxicity. ${ }^{3}$ In addition to these important biological activities, the replacement of an oxygen atom in carbohydrates by sulfur induces a number of interesting changes in the chemical properties. Cyclic equilibria are affected, ${ }^{4}$ and chemical reactivities may be modified. ${ }^{5}$ Interesting reactions of 5 -thiopyranose derivatives, which involved transannular participation of the ring sulfur atom, have been recently reported.6,7

Synthesis of 4 -thiohexofuranose derivatives, having D-gluco, ${ }^{8}$ D-manno, ${ }^{9} 6$-deoxy-D-gluco, ${ }^{10} 6$-deoxy-D-ido, ${ }^{11}$ and 6-deoxy-D-gulo ${ }^{12}$ configurations, have been described. However, the synthesis of 4-thio-D-galactofuranose was not reported. This sugar was particularly interesting for us since we have found galactofuranose $\mathrm{e}^{13}$ as a constituent of a glycoconjugate from membranes of a parasitic flagellated protozoan, Trypanosoma cruzi, the agent of Chagas' disease, a chronic ailment afflicting several millions in South

(1) Horton, D.; Wander, J. The Carbohydrates: Chemistry and Biochemistry; Pigman, W., Horton, D., Eds.; Academic: New York, 1980; Vol. IB, pp 799-842.

(2) Kim, J. H.; Kim, S. H.; Hahn, W.; Song, C. W. Science 1978, 200, 206.

(3) Maugh, T. H. II Science 1974, 186, 431.

(4) Clayton, C. J.; Hughes, N. A. Carbohydr. Res. 1967, 432

(5) Clegg, W.; Hughes, N. A.; Al-Masoudi, N. A. L. J. Chem. Soc., Chem. Commun. 1979, 300; 1979, 320 .

(6) Hashimoto, H.; Hideya, Y. Tetrahedron Lett. 1988, 29, 1939.

(7) (a) Al-Masoudi, N. A. L.; Hughes, N. A. J. Chem. Soc., Perkin

Trans. 1 1987, 2061. (b) Hughes, N. A.; Wood, C. J. Ibid. 1986, 695.

(8) Vegh, L.; Hardegger, E. Helv. Chim. Acta 1973, 56, 208.

(9) Shah, R. H.; Bose, J. L.; Bahl, O. P. Carbohydr. Res. 1979, 77, 107

(10) Owen, L. N.; Rage, P. L. J. Chem. Soc. C 1966, 1291

(11) Gross, B.; Oriez, F. X. Carbohydr. Res. 1974, 36, 385

(12) Boigegrain, R. A.; Gross, B. Carbohydr. Res. 1975, 41, 135.

(13) (a) Lederkremer, R. M.; Casal, O. L.; Alves, M. J. M.; Colli, W.

FEBS Lett. 1980, 116, 25. (b) Lederkremer, R. M.; Casal, O. L.; Couto,

A.; Colli, W. Eur. J. Biochem. 1985, 151, 539. and Central America. The presence of galactose in the furanoid configuration in the protozoan establishes an important structural feature compared with mammalian cells, in which, apparently, no galactofuranose has been found.

The many attractive synthetic possibilities exhibited by thio sugars, and the potential antimetabolite activity against enzyme systems of $T$. cruzi, prompted us to synthesize 4-thio-D-galactofuranose. Furthermore, as only scarce spectral data for 4-thiofuranoses are available, we analyzed in detail the ${ }^{1} \mathrm{H}$ and ${ }^{13} \mathrm{C}$ NMR spectra of the products obtained in this work.

\section{Results and Discussion}

4-Thiogalactofuranose (15) and derivatives were synthesized from readily available and unexpensive methyl $\alpha$-D-glucopyranoside (1). The approach for the synthesis of 15 involved the preparation of a partially protected derivative of 1 , having $\mathrm{HO}-4$ free. The 2,3,6-tri- $O$-benzoyl derivative of 1 was achieved by selective benzoylation of 1 with $N$-benzoylimidazole. Benzoylations of 1 , under different conditions, ${ }^{14}$ have indicated a lower reactivity for $\mathrm{HO}-4$. Also, on selective esterifications of D-glucose, ${ }^{15}$ 6 -deoxy-D-glucose, ${ }^{16}$ and 2-deoxy-D-arabino-hexose, ${ }^{17}$ the HO-4 remained unreactive. For the partial acylation of sugars, besides of the commonly used acid chlorides or acid anhydrides, other acid derivatives have been employed. ${ }^{18 \mathrm{~b}}$ For example, $N$-benzoylimidazole will selectively benzoylate carbohydrates. ${ }^{18}$

Benzoylation of 1 with $N$-benzoylimidazole ( $3.6 \mathrm{~mol}$ per mole of 1 ) in refluxing acetonitrile afforded a mixture of benzoylated derivatives $(\mathbf{2 a - d})$. The mixture, when analyzed by column chromatography, indicated the 2,3,6tribenzoate $2 \mathrm{c}(71 \%)$ was the main product. Other products were the isomeric 2,4,6-tribenzoate $2 \mathbf{b}(2.7 \%)$, the perbenzoate $2 \mathrm{a}(10.6 \%)$, and dibenzoate $2 \mathrm{~d}(13.2 \%)$. These results indicate the order of substitution to be HO-6

(14) (a) Ogawa, T.; Matsui, M. Tetrahedron 1981, 37, 2263. (b) Williams, J. M.; Richardson, A. C. Ibid. 1967, 23, 1369.

(15) Batey, J. F.; Bullock, C.; O'Brien, E.; Williams, J. M. Carbohydr. Res. $1975,43,43$

(16) Kondo, Y.; Miyahara, K.; Kashimura, N. Can. J. Chem. 1973, 51, 3272

(17) Fiandor, J.; De Las Heras, F. G. Carbohydr. Res. 1986, 153, 325

(18) (a) Horton, D.; Priebe, W.; Varela, O. Carbohydr. Res. 1985, 144 317. (b) Haines, A. H. Adv. Carbohydr. Chem. Biochem. 1976, 33, 11. 
Table I. 'H NMR Chemical Shift and Coupling Constant Data

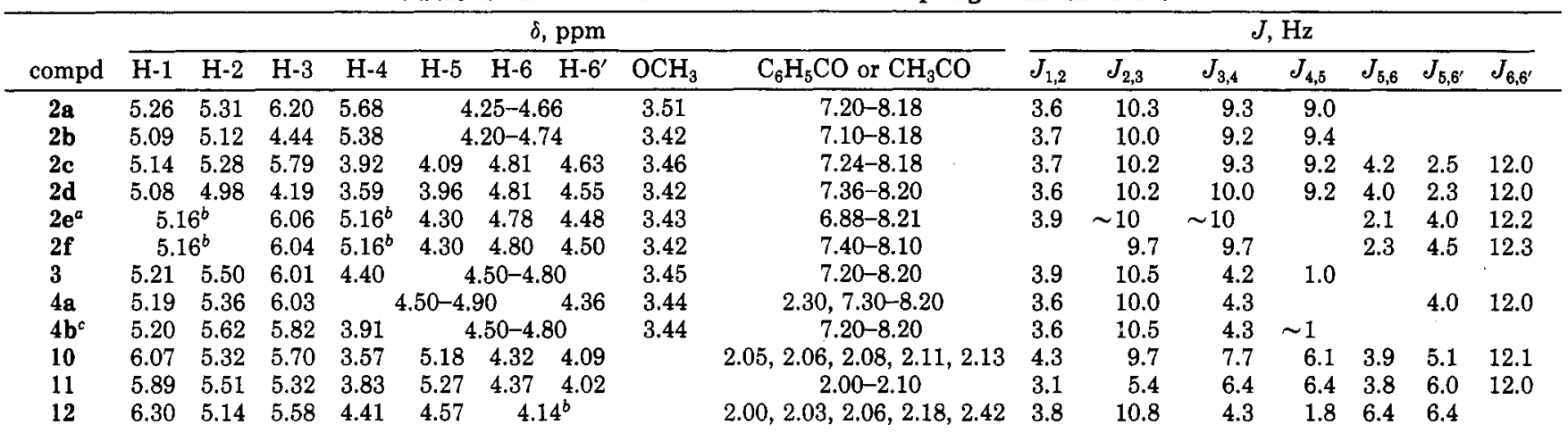

${ }^{a}$ It showed at $2.17 \mathrm{ppm}$ a singlet $(3 \mathrm{H})$ due to the $\mathrm{CH}_{3} \mathrm{C}_{6} \mathrm{H}_{4}$. ${ }^{b}$ The $\delta$ value given corresponds to the center of the multiplet of the overlapped signals. ' It showed at $1.75 \mathrm{ppm}$ a doublet due to $\mathrm{SH}\left(J_{\mathrm{SH}, \mathrm{H}-4}=9.0 \mathrm{~Hz}\right)$, which disappeared on deuteration.

Table II. ${ }^{13} \mathrm{C}$ NMR Chemical Shift Data

\begin{tabular}{|c|c|c|c|c|c|c|c|c|c|c|c|}
\hline compd & $\mathrm{C}-1$ & C-2 & $\mathrm{C}-3$ & $\mathrm{C}-4$ & C-5 & $\mathrm{C}-6$ & $\mathrm{OCH}_{3}$ & $\mathrm{C}_{6} \mathrm{H}_{5} \mathrm{CO}$ & $\mathrm{CH}_{3} \mathrm{CO}$ & $\mathrm{C}_{6} \mathrm{H}_{5} \mathrm{CO}$ & $\mathrm{CH}_{3} \mathrm{CO}$ \\
\hline $2 \mathbf{a}$ & 96.9 & 71.9 & 70.3 & 69.5 & 67.6 & 63.0 & 55.6 & $128.1-133.4$ & & $165.1-165.9$ & \\
\hline $2 \mathbf{b}$ & 97.0 & 74.0 & 70.2 & 72.2 & 67.4 & 63.2 & 55.5 & $128.0-133.3$ & & $165.9-166.1$ & \\
\hline $2 c$ & 96.9 & 71.5 & 73.5 & $69.8^{*}$ & $69.5^{*}$ & 63.5 & 55.2 & $128.2-133.0$ & & $165.7,166.6,166.7$ & \\
\hline $2 d$ & 97.2 & 73.7 & 71.6 & 70.7 & 69.5 & 63.7 & 55.3 & $128.3-133.2$ & & $166.2-166.9$ & \\
\hline $2 \mathbf{e}^{a}$ & 96.6 & 71.9 & 69.6 & 75.4 & 67.5 & 62.3 & 55.6 & $127.2-144.7$ & & $165.0-165.8$ & \\
\hline $2 f$ & 96.6 & 71.8 & 69.6 & 76.0 & 67.4 & 62.5 & 55.6 & $128.3-135.3$ & & $164.9-165.7$ & \\
\hline $3^{b}$ & 97.3 & $69.0^{*}$ & $68.8^{*}$ & 54.5 & 66.1 & 63.5 & 55.8 & $128.3-133.5$ & & $165.4,165.5,165.6$ & \\
\hline $4 \mathbf{a}$ & 97.4 & 70.4 & $68.3^{*}$ & 47.2 & $66.7^{*}$ & 64.2 & 55.4 & $128.2-133.1$ & 30.6 & $165.6-165.8$ & 192.7 \\
\hline $4 b$ & 97.3 & $69.6^{*}$ & $69.0^{*}$ & 42.8 & 67.0 & 64.7 & 55.4 & $128.0-133.3$ & & $163.3-166.0$ & \\
\hline $\mathbf{5}^{\mathrm{c}}$ & 100.7 & $70.6^{*}$ & $69.8^{*}$ & 45.5 & $69.5^{*}$ & 63.1 & 55.0 & & & & \\
\hline 10 & 74.6 & 76.7 & 74.1 & 45.1 & 71.3 & 63.5 & & & $21.2-21.7$ & & $170.1-170.7$ \\
\hline 11 & $80.3^{*}$ & 80.3 & $76.1^{*}$ & 49.8 & 69.0 & 63.6 & & & $20.7-20.8$ & & $169.5-170.1$ \\
\hline 12 & 89.6 & 67.5 & 67.5 & 46.3 & 69.3 & 63.2 & & & $20.5-20.9,30.7$ & & $169.5-170.2,193.1$ \\
\hline
\end{tabular}

${ }^{a} \mathrm{CH}_{3} \mathrm{C}_{6} \mathrm{H}_{4}$ appeared at $21.4 \mathrm{ppm}$. ${ }^{b} \mathrm{SCN}$ appeared at $110.8 \mathrm{ppm}$. ' Recorded in $\mathrm{CD}_{3} \mathrm{OD}$. *Signals could be exchanged.

$>\mathrm{HO}-2>\mathrm{HO}-3>\mathrm{HO}-4$, similar to observations for benzoylations of 1 with other reagents. 14

The structure of the substituted derivatives was confirmed by their spectroscopic data (Table I). The signals of $\mathrm{H}-3(\delta 4.44)$ in $\mathbf{2 b}$, and $\mathrm{H}-4(\delta 3.92)$ in $2 \mathbf{c}$, were shifted downfield in $1.76 \mathrm{ppm}$ by benzoylation of $\mathrm{HO}-3$ or $\mathrm{HO}-4$, respectively. The signals of the vicinal protons, $\mathrm{H}-2, \mathrm{H}-4$ in $\mathbf{2 b}$ and $\mathrm{H}-3, \mathrm{H}-\mathbf{5}$ in $\mathbf{2 c}$, were shifted downfield less than $0.5 \mathrm{ppm}$ when $\mathrm{HO}-3$ or HO-4 were benzoylated. Benzoylation of either $\mathrm{HO}-3$ or $\mathrm{HO}-4$ in $2 \mathrm{~d}$ produced a downfield displacement for the signals of $\mathrm{H}-3$ or $\mathrm{H}-4$ in 1.60 and 1.79 ppm, respectively. However, simultaneous benzoylation of $\mathrm{HO}-3$ and $\mathrm{HO}-4$ in $2 \mathrm{~d}$ shifted more than $2.0 \mathrm{ppm}$ downfield $\mathrm{H}-3$ and $\mathrm{H}-4$.

When the ${ }^{13} \mathrm{C}$ NMR data of compounds $2 \mathbf{b}-\mathbf{d}$ were compared with those of compound $2 \mathbf{a}$, reported in the literature, ${ }^{19}$ some ambiguities appeared. We have now determined the chemical shifts of compound $2 \mathbf{a}$, by using selective proton decoupling. The reassigned values (Table II), are in agreement with those reported ${ }^{20}$ for the acetylated analogue of $2 \mathbf{a}$. Introduction of a benzoyl group into HO-3 in $\mathbf{2 b}$ or HO-4 in 2c causes a small displacement of the $\alpha$-carbon atom (C-3 or C-4, respectively) but a larger (2-3 ppm) upfield shift of the $\beta$-carbons. The same result was observed for monobenzoylation of compound $2 \mathrm{~d}$ to give $2 \mathbf{b}$ or 2c, but in this case the downfield shift of the $\alpha$-carbon atom was somewhat larger $(1.5,1.9 \mathrm{ppm}$, respectively).

The selective benzoylation of methyl $\alpha$-D-glucopyranoside (1) with $N$-benzoylimidazole gave a comparable yield of the tribenzoate 2c but involved less expensive reagents than the stannylation method. ${ }^{14 a}$ The use of

(19) Bock, K.; Pedersen, C. J. Chem. Soc., Perkin Trans, 2 1974, 293 27.

(20) Bock, K.; Pedersen, C. Adv. Carbohydr. Chem. Biochem. 1983, 41,
$N$-benzoylimidazole as acylating agent was convenient as the byproducts are produced in low yields, facilitating the purification of $2 \mathrm{c}$. In contrast, partial benzoylation of 1 with benzoyl chloride-pyridine ${ }^{14 b}$ gives large proportions of the 2,4,6-tribenzoate (2b), making the isolation of $2 \mathrm{c}$ difficult.

On treatment of the crude product of benzoylation (2a-d) with $p$-toluenesulfonyl chloride (tosyl chloride) in pyridine, the tosylate $2 \mathrm{e}$ crystallized from the reaction mixture. Treatment of the crude product of benzoylation of 1 with $p$-bromobenzenesulfonyl chloride (brosyl chloride) gave an amorphous solid when the reaction mixture was poured into ice-water. Crystallization of this solid could not be induced, although brosylate $2 f$ was the main component $(\sim 90 \%)$ as estimated from its ${ }^{1} \mathrm{H}$ NMR spectrum. This material was successfully employed in the next reaction step without further purification. Analytically pure, crystalline brosylate $2 \mathrm{f}$ was obtained by brosylation of chromatographically purified 2,3,6-tri- $O$-benzoyl derivative 2c. The ${ }^{13} \mathrm{C}$ NMR spectra of $2 \mathrm{e}$ and $2 \mathrm{f}$ showed that tosylation or brosylation of the HO-4 in $2 \mathrm{c}$ caused a downfield shift for C-4, and an upfield displacement for C-3 and C-5, as observed for the sulfonylation of other monosaccharides. ${ }^{21}$

The next step of the synthesis involved the displacement of the 4-sulfonate of $2 \mathrm{e}$ or $2 \mathrm{f}$ by a nucleophile precursor of thiol. Substitution of sulfonyloxy groups of suitably protected sugar derivatives, by different nucleophiles, was examined by several authors, ${ }^{22}$ and factors influencing the reactivity, such as the geometry of the molecule and the

(21) Liptåk, A.; Nănåsi, P.; Neszmêlyi, A.; Wagner, H. Carbohydr. Res. $1980,86,133$

(22) (a) Richardson, A. C. Carbohydr. Res. 1969, 10, 395. (b) Ball, D. H.; Parrish, F. W. Adv. Carbohydr. Chem. 1968, 23, 233; Adv. Carbohydr. Chem. Biochem. 1969, 24, 139. 
nucleophilicity of the attacking group, have been evaluated. Since potassium thioacetate and potassium thiocyanate were the agents more commonly used, ${ }^{1,23}$ the reaction of $2 \mathbf{e}$ with those nucleophiles, under various conditions, was studied. Potassium thioacetate in aprotic, polar solvents such as $N, N$-dimethylformamide (DMF) or dimethyl sulfoxide did not react with $2 \mathrm{e}$ at low temperature and when heated over $100^{\circ} \mathrm{C}$ resulted in extensive decomposition. However, the substitution took place smoothly with potassium thiocyanate in DMF, under nitrogen, at $110 \pm$ $5{ }^{\circ} \mathrm{C}$. After $48 \mathrm{~h}$ the reaction was almost complete, and compound 3 was readily isolated by column chromatography in $60-75 \%$ yield. The replacement of tosylate by a thiocyano group at C-4 produced an upfield shift for the $\mathrm{H}-4$ signal, and the values of the coupling constants between $\mathrm{H}-3, \mathrm{H}-4(J=4.2 \mathrm{~Hz})$ and $\mathrm{H}-4, \mathrm{H}-5(J=1.0 \mathrm{~Hz})$ were consistent with the change from the gluco to the galacto configuration. This configurational change was confirmed by comparing the ${ }^{13} \mathrm{C}$ NMR spectrum of 3 and 2e. The observed shift for the C-2 signal of 3 to higher field was caused by a syn-axial interaction, ${ }^{24}$ between the $\mathrm{H}-2$ and the $\mathrm{C}-4$ substituent, absent in 2 e. The strong upfield shifting $(20.9 \mathrm{ppm})$ of the C-4 signal in 3 was due to the shielding effect of the sulfur atom on C-4. ${ }^{25}$ Although thermal rearrangements of the thiocyanates to isothyocyanates have been described, ${ }^{23}$ we have not observed the formation of the latter compounds during the nucleophilic substitution at high temperatures. The ${ }^{13} \mathrm{C}$ NMR spectrum of 3 showed the carbon signal of the thiocyano group at $110.8 \mathrm{ppm}$, similar to that reported for alkyl thiocyanates $^{26}(110-115 \mathrm{ppm})$ but well distinguished from that found for sugar isothiocyanates ${ }^{23}(\sim 144 \mathrm{ppm})$.

Since nucleophilic displacements of sulfonates have been reported ${ }^{27}$ to take place more efficiently in the presence of crown ethers, the conversion of $2 \mathbf{e}$ into 3 was performed with potassium thiocyanate and 18-crown-6 in DMF, at $110^{\circ} \mathrm{C}$. The reaction required a shorter time $(17 \mathrm{~h})$ for completion, but the yield of 3 was unimproved.

The nucleophilic substitution was also conducted by starting from the brosyl derivative $2 \mathrm{f}$, with potassium thiocyanate in DMF at $110^{\circ} \mathrm{C}$, under nitrogen. Consistent with the fact that brosyloxy is a better leaving group than tosyloxy, ${ }^{28}$ the reaction was completed more rapidly and with hither yields than when starting from $2 e$. The crude brosylate $2 f$ was used for the preparation of 3 , which was isolated in $54 \%$ from 1 after column chromatography.

Reduction of the thiocyano group of 3 with zinc-acetic acid in the presence of acetic anhydride afforded the $S$ acetyl-4-thio derivative $4 \mathbf{a}$. The ${ }^{1} \mathbf{H}$ NMR spectrum of $4 \mathbf{a}$ showed the methyl of $S$-acetyl at $2.30 \mathrm{ppm}$, and in the ${ }^{13} \mathrm{C}$ NMR spectrum, the methyl and carbonyl groups of the thioacetate at 30.6 and $192.7 \mathrm{ppm}$, respectively. The crystalline free thiol $\mathbf{4 b}$ was obtained by reduction of 3 with zinc-acetic acid. The IR spectrum of $4 \mathrm{~b}$ showed the characteristic $\mathrm{SH}$ absorption at $2560 \mathrm{~cm}^{-1}$. The presence of a free $\mathrm{SH}$ group was confirmed by the ${ }^{1} \mathrm{H}$ NMR spectrum of $4 \mathrm{~b}$ since, on deuteration, the doublet at $1.75 \mathrm{ppm}$ (SH) disappeared and the multiplet due to $\mathrm{H}-4$ collapsed to a double doublet. Acetylation of $4 \mathrm{~b}$ gave the $4-S$-acetyl

(23) Witczack, Z. J. Adv. Carbohydr. Chem. Biochem. 1986, 44, 91 (24) Ferrier, J. M. T. P. Int. Rev. Sci. Org. Chem., Series Two 1976, 7,5 . 144.

(25) Berman, E.; Daman, M. E.; Dill, K. Carbohydr. Res. 1983, 116,

(26) Breitmaier, E.; Voelter, W. Carbon-13 NMR Spectroscopy, 3rd ed.; VCH: New York, 1987; p 245

(27) (a) Liotta, C. L.; Harris, H. P. J. Am. Chem. Soc. 1974, 96, 2252. (b) Liotta, C. L.; Harris, H. P.; Gonzalez, T.; Smith, K. Tetrahedron Lett. $1974,2417$.

(28) Horton, D.; Hutson, D. H. Adv. Carbohydr. Chem. 1963, 18, 123.
Scheme I
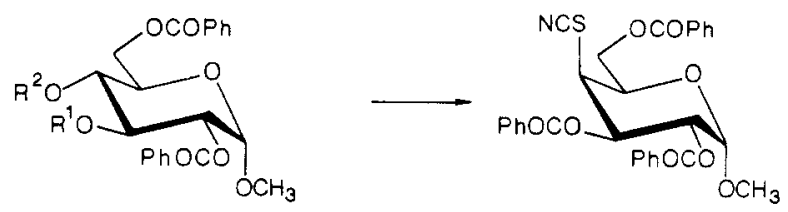

$2 \mathrm{a}: R^{1}, R^{2}=\mathrm{PnCO}$

b: $R^{1}=H_{;} R^{2}=P h C O$

c: $R^{1}=P h C O: R^{2}=H$

d: $R^{1} \cdot B^{2}=H$

e: $\mathrm{R}^{1}=\mathrm{PhCO}: \mathrm{R}^{2}=\mathrm{P}-\mathrm{CH}_{3} \mathrm{PhSO}_{2}$

$\because \mathrm{R}^{1}=\mathrm{PhCO}: \mathrm{R}^{2}=\mathrm{p}-\mathrm{BrPhSO}_{2}$

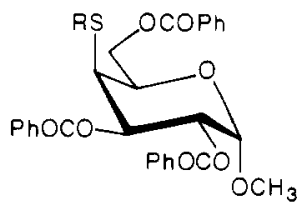

4a: $\mathrm{R}=\mathrm{CH}_{3} \mathrm{CO}$

b: $R=H$

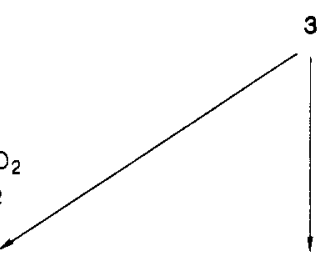

3
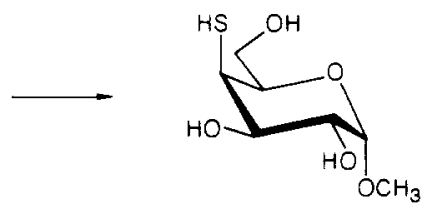

$\mathbf{5}$

derivative 4a. Treatment of $\mathbf{4 b}$ with methanolic sodium methoxide produced complete $\mathrm{O}$-deacylation to give compound 5. Sodium methoxide has been also employed ${ }^{23}$ for the direct hydrolysis of the thiocyano group to thiol. Treatment of compound 3 with sodium methoxide gave a mixture from which the thiol $\mathbf{5}$ was isolated by column chromatography in $50 \%$ yield. The structure of 5 , obtained by alkaline methanolysis of 3 , as well as from $4 \mathrm{~b}$, was undoubtedly determined. The IR spectrum of $\mathbf{5}$ had the absorption of the SH group at $\nu 2550 \mathrm{~cm}^{-1}$. The ${ }^{13} \mathrm{C}$ NMR spectrum of 5 showed the signals for the anomeric and for the methoxyl carbons at 100.7 and $55.0 \mathrm{ppm}$, respectively. The signal for C-4, bonded to sulfur, appeared at high field $(\delta 45.5)$.

In order to favor ring contraction to the 4-thiofuranose, acidic hydrolysis of the methyl glycoside 5 was attempted. The reaction was conducted under various conditions and with different acids, but decomposition always occurred. However, acetolysis of $\mathbf{5}$, as reported for some methyl 4thiopyranosides, ${ }^{1}$ took place cleanly, affording a syrupy product that was separated by column chromatography in two fractions. From the secondly eluted fraction a crystalline compound was obtained whose ${ }^{13} \mathrm{C}$ NMR spectrum showed no signals for the thioacetyl group and whose C-1 and C-4 signals were strongly shifted upfield, indicating a sulfur-containing furanoid ring. The coupling constant $(J=4.3 \mathrm{~Hz})$ between $\mathrm{H}-1$ and $\mathrm{H}-2$ from the ${ }^{1} \mathrm{H}$ NMR spectrum suggested ${ }^{29}$ an $\alpha$-configuration for $\mathrm{C}-1$. The coupling constants and chemical shifts for the other protons of the ring indicated a 4-thiogalactofuranose structure (10) for the compound, which would exist in a preferential ${ }^{2} T_{3}$ (D) conformation. In this conformation the anomeric acetyl group is quasi-axially oriented, satisfying the stereoelectronic requirements ${ }^{30}$ of the ring sulfur atom (anomeric effect); the other substituents, including the bulky lateral chain, are quasi-equatorially disposed. Furthermore, the $\mathrm{H}-4$ and $\mathrm{H}-5$ coupling constant $(6.1 \mathrm{~Hz})$ would dictate a sickle rotamer for the side chain, in order to avoid a parallel interaction between the acetate groups at $\mathrm{C}-5$ and at $\mathrm{C}-1 .{ }^{30}$ The mass spectrum of 10 showed, as described for other 4-thiofuranose derivatives, ${ }^{31}$ the peaks

(29) Bundle, D. R.; Lemieux, R. U. Methods Carbohydr. Chem. 1976, $7,79$.

(30) Angyal, S. J. Carbohydr. Res. 1979, 77, 37. 377 . 


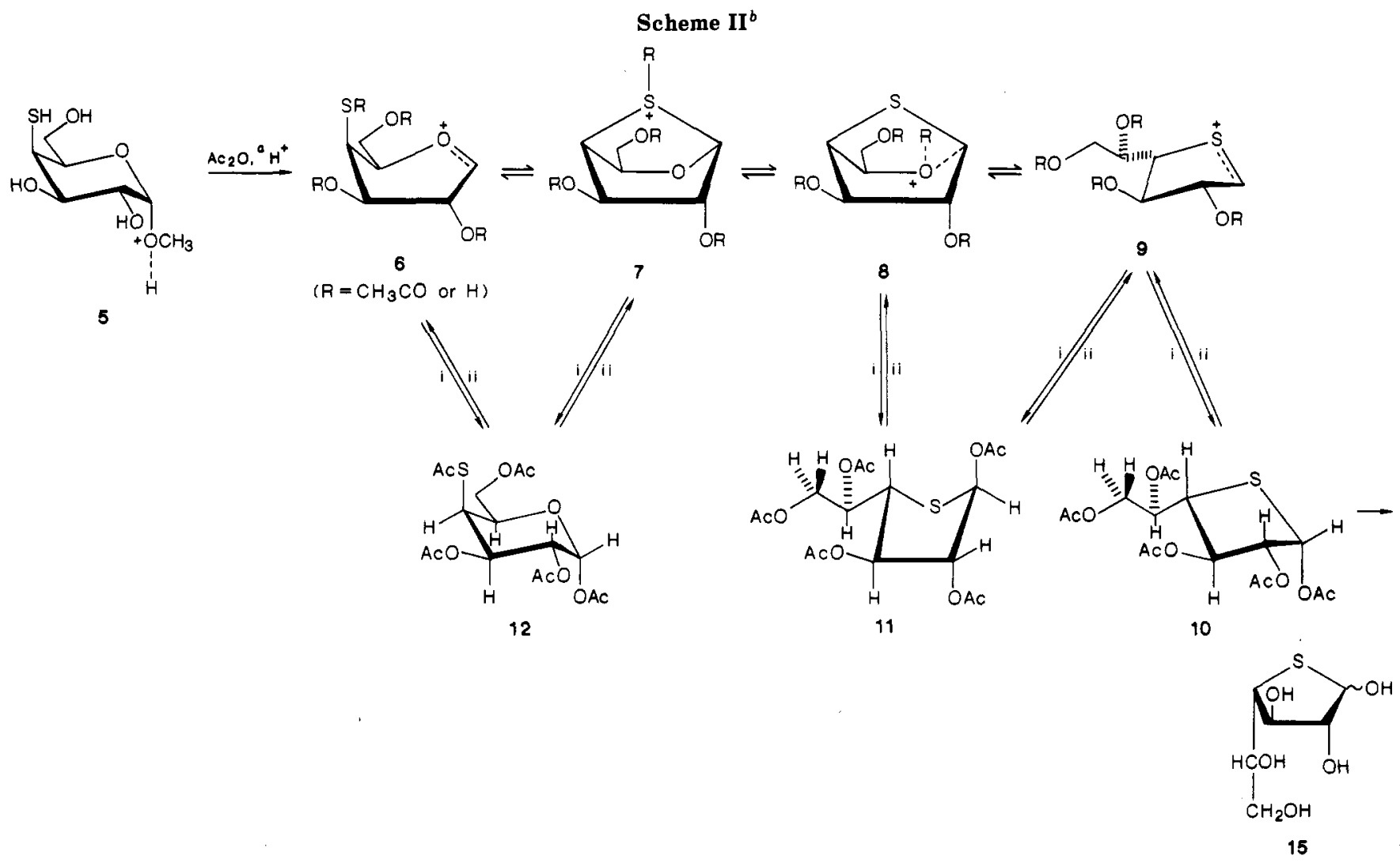

${ }^{a} \mathrm{Ac}=\mathrm{CH}_{3} \mathrm{CO} .{ }^{b}$ (i) $\mathrm{CH}_{3} \mathrm{CO}_{2} \mathrm{H},-\mathrm{H}^{+}$; (ii) $\mathrm{H}^{+},-\mathrm{CH}_{3} \mathrm{CO}_{2} \mathrm{H}$.

formed from the molecular ion by elimination of the acetoxy substituent at C-1 $(\mathrm{m} / z 347)$ or acetic acid (346) with higher intensity than the peak arising by loss of the exocyclic chain (261) from the molecular ion. This behavior is markedly different from that shown by penta$O$-acetylgalactofuranose. ${ }^{32}$ The successive loss of acetic acid from the peak at $\mathrm{m} / z 346$ would account for the high intense peaks of the sequence $346 \rightarrow 286 \rightarrow 226$, which may also undergo the elimination of ketene to give $m / z 304$, 244 , and 184 , respectively. The base peak could arise by loss of ketene from the ion at $m / z 184$.

The first chromatographic fraction showed to be a mixture of two compounds, which were separated by HPLC. The major component was identified as penta- $O$ acetyl-4-thio- $\beta$-D-galactofuranose (11), by comparison of its spectral properties with those of 10 . The mass spectrum of 11 was almost identical to that of 10 , and the $\beta$-anomeric configuration for 11 was established by the $\mathrm{H}-1-\mathrm{H}-2$ coupling constant $(3.1 \mathrm{~Hz})$ characteristic of 1,2-trans-disposed protons. ${ }^{29}$ The other coupling constants for the ring hydrogens would suggest an $E_{\mathrm{S}}$ (D) conformation for 11 , as observed for common $\beta$-galactofuranosides. ${ }^{30}$ The minor component (12) showed in the ${ }^{13} \mathrm{C}$ NMR spectrum the signals for methyl (30.7 ppm) and carbonyl groups (193.1 $\mathrm{ppm}$ ) of the thioacetate, the anomeric carbon at $89.6 \mathrm{ppm}$, coincident with the value reported for penta- $O$-acetyl $\alpha$ D-galactopyranose ${ }^{20}$ indicating a pyranoid structure for 12. The $\alpha$-configuration for $\mathrm{C}-1$ was confirmed by the $\mathrm{H}-1-\mathrm{H}-2$ coupling constant $(J=3.8 \mathrm{~Hz})$ in the ${ }^{-1} \mathrm{H}$ NMR spectrum of 12. The methyl group of the thioacetate appeared at $2.42 \mathrm{ppm}$. The more intense peaks in the mass spectrum of 12 appeared, with respect to the main peaks in the spectrum of penta- $O$-acetylgalactopyranose, ${ }^{32}$ displaced for 16 mass units due to the replacement of the

(32) Biemann, K.; DeJongh, D. C.; Schnoes, H. K. J. Am. Chem. Soc. $1963,85,1763$. oxygen atom at C-4 by sulfur.

The product distribution in the acetolysis of 5 was determined from the integrated ${ }^{1} \mathrm{H}$ NMR spectrum and by analytical HPLC of the reaction mixture, both being in good agreement with the preparative yields. A large proportion of anomeric 4-thiofuranose pentaacetates was formed, as shown by the 4:2:1 ratio found for compounds 10:11:12. Furthermore, acetolysis of one of these products led to a mixture of 10:11:12 in the same ratio obtained from acetolysis of 5. A possible explanation for ring contraction during acetolysis of 4-thiopentopyranose derivatives was given by Goodman and co-workers, ${ }^{33}$ who have proposed participation of the 4-thio substituent to form an intermediate sulfonium ion, precursor of the 4-thiofuranoses. Several examples are reported on the participation of sulfur to produce stabilized sulfonium ions, ${ }^{34}$ and recent studies $^{6,7}$ on the reactivity of 5-thiopyranoses have demonstrated that ring contraction or displacement reactions proceeded via sulfonium ions. The isolation of bicyclic systems containing both sulfur and oxygen from the mixture of hydrolysis or methanolysis of thio sugars ${ }^{35}$ supported the formation of bridged sulfonium ions during acetolysis. The results on acetolysis of $\mathbf{5}$, as well as other reports in the literature for 4-thiopyranose derivatives, were rationalized in terms of the stereoelectronic effects, which, by affecting the stability of the ionic intermediates, would be expected to control the stereochemical course of the reaction. When compound $\mathbf{5}$ is dissolved in acetic acid-acetic anhydride-sulfuric acid mixture, acetylation occurred rapidly, and simultaneous protonation of the methoxy group promoted the cleavage of the glycosidic

(33) Reist, E. J.; Gueffroy, D. E.; Goodman, L. J. Am. Chem. Soc. 1964, 86,5658 .

(34) Capon, B.; McManus, S. P. Neighboring group participation; Plenum Press: New York, 1976; Vol. 1, p 195.

(35) (a) Nam Shin, J. E.; Perlin, A. S. Carbohydr. Res. 1980, 84, 315. (b) Cox, J. M.; Owen, L. N. J. Chem. Soc. C 1967, 1121. 
linkage to afford the oxonium ion 6 (Scheme II). The thio group, axially disposed in 6 , is in a favorable position for attacking the anomeric carbon, to produce a bicyclic sulfonium ion (7). However, the anchimeric assistance of sulfur could occur simultaneously with the displacement of the methoxy group to give an internally solvated ion-pair intermediate, similar to that suggested by Noyce and Bastian $^{36}$ for the acetolysis of trans-(4-methoxycyclohexyl)toluene- $p$-sulfonate. The sulfonium ion 7 would be a stable bicyclic system since the substituents are free of eclipsing or 1,3-diaxial interactions, except for the "hockey sticks" effect ${ }^{37}$ of the axial lone pair of the ring-oxygen atom and the acetate at C-2. Further rearrangement of 7 , for example, through the intermediate oxonium ion 8 , would lead to the sulfonium ion 9, as sulfur can effectively stabilize a positive charge by electron donation. ${ }^{34}$ The sulfonium ion 9 would be the precursor of the 4-thiofuranoses 10 and 11. Apparently, no unstabilizing factors are developed in the ionic species that lead to the main product, the $\alpha$-isomer (10), which would exist, as mentioned above, in the stable ${ }^{2} T_{3}$ (D) conformation. However, attack by acetic acid from the $\beta$-face of 9 would generate a parallel interaction ${ }^{37}$ between the sulfur lone pair and the C-2 acetoxy group in 11 .

Similar to the results here on acetolysis of the 4-thiohexopyranose with a galacto configuration, an ido derivative $^{11}$ (methyl 2,3-di-O-acetyl-4-S-acetyl-6-deoxy-4-thio$\alpha$-D-idopyranoside) underwent ring contraction to give the anomeric mixture of acetylated 6-deoxy-4-thio-D-idofuranose. In contrast, D-manno, ${ }^{9} 6$-deoxy-D-gulo, ${ }^{12}$ and 6-deoxy-D-altro ${ }^{11}$ derivatives gave by acetolysis the pyranoid pentaacetates as main products. The axial or equatorial orientation of the 4-thiol group was considered to be responsible for the different behavior of the ido and altro isomers. ${ }^{11}$ However, in spite of the axial orientation of the 4-S-acetyl group, acetolysis of 4-thio-D-gulopyranoside gave only $3 \%$ of the 4 -thiofuranose derivative. ${ }^{12}$ The virtual absence of ring contraction products was attributed to the instability of the furanoid compounds, because of the crowding of the substituents on the same side of the ring. Although a 4-thio-D-mannopyranose derivative having the same relative configuration as the gulo isomer could not be acetolyzed to the 4-thiofuranoid acetates, an anomeric mixture of the latter was obtained by deacylation of 1,2,3,6-tetra- $O$-acetyl-4-S-benzoyl-4-thio- $\alpha$ D-mannopyranose followed by acetylation. These results indicate that crowding of substituents will not explain the failure in ring contraction during acetolysis of the 4-thiomanno- and 4-thio-gulopyranoid derivatives. As for the acetolysis of $\mathbf{5}$, these results may be interpreted by taking into account the stability of the ionic intermediates of the type of 7. Thus, the bicyclic sulfonium ion having an ido configuration (13) would readily be formed because of the favored axial orientation of the thio group in the ${ }^{4} C_{1}$ (D) conformation and the absence of unstabilizing interactions among the substituents on $\mathrm{C}-2, \mathrm{C}-3$, and the acetoxymethyl group. In spite of the appropriate disposition of the thio group in the gulo isomer, the sulfonium ion 14 would be unstabilized by an eclipsing interaction between the acetoxy groups on C-2-C-3, and a parallel interaction ${ }^{37}$ of the lone pair of the ring-oxygen atom, and the acetoxy group at $\mathrm{C}-2$, which would explain the very low proportion of ring-contraction products. Similarly, the unstabilizing factors in the sulfonium ion intermediate, formed through an unfavorable chair inversion during the acetolysis of

(36) Noyce, D. S.; Bastian, B. N. J. Am. Chem. Soc. 1960, 82, 1246. (37) Zefirov, N. S.; Blagoveshchensky, V. S.; Kazimirchik, I. V.; Surova, N. S. Tetrahedron $1971,27,3111$.

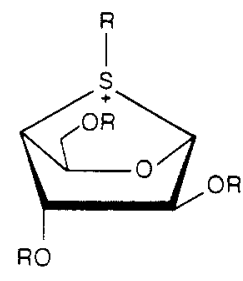

13

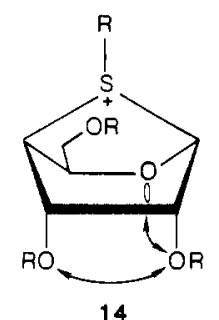

4-thiomannopyranose ${ }^{9}$ and 4-thioglucopyranose ${ }^{8,10}$ derivatives, would explain the absence or low yield of 4-thiofuranoses.

Deacetylation of 10 gave the free 4-thio-D-galactose (15). The ${ }^{13} \mathrm{C}$ NMR spectrum of $\mathbf{1 5}$ showed the presence of the furanoid forms, but no signals for the anomeric carbons of the pyranoses were detected. The signals for C- 1 and C-4 of the furanoses were shifted upfield, because of the shielding effect of the sulfur ring atom. The anomeric carbons were difficult to differentiate from the other carbons bonded to oxygen. However, signals for C-4 appeared in a clear region of the spectrum, and their relative intensities allowed the estimation of the anomeric composition of the mixture, being the $\alpha: \beta$ ratio 2:1. Cyclization to the furanoid ring should be expected because of the high nucleophilicity of the thiol group. ${ }^{1}$ The stability of the sulfur-containing ring is evidenced in the very slow mutarrotation of 4-thiogalactose as shown by other 4- and 5 -thio sugars.

\section{Experimental Section}

General Procedures. Melting points were determined in a Thomas-Hoover apparatus and are uncorrected. Optical rotations were measured with a Perkin-Elmer 141 polarimeter for $1 \%$ solutions in $\mathrm{CHCl}_{3}$ at $25{ }^{\circ} \mathrm{C}$. IR spectra were recorded on a Perkin-Elmer 710B spectrophotometer with the polystyrene absorption at $1602 \mathrm{~cm}^{-1}$ as the reference. MS were run on a Varian MAT CH7A spectrometer at $70 \mathrm{eV} .{ }^{1} \mathrm{H}$ and ${ }^{13} \mathrm{C}$ NMR spectra were recorded with a Varian XL 100 spectrometer at 100.1 and $25.2 \mathrm{MHz}$, respectively, for solutions in $\mathrm{CDCl}_{3}$, with tetramethylsilane as internal standard. The apparent coupling constants (in hertz) reported are the directly measured line spacings from the ${ }^{1} \mathrm{H}$ NMR spectra. Signal assignments for the ${ }^{13} \mathrm{C}$ NMR spectra were made on the basis of selective heteronuclear decoupling experiments. Data are shown in Tables I and II. Analytical thin-layer chromatography (TLC) was performed on $0.25 \mathrm{~mm}$ silica gel $60 \mathrm{~F}-254$ (Merck) aluminium supported plates with 9:1 toluene-ethyl acetate as solvent. Detection was effected by spraying the plates with $5 \% \mathrm{H}_{2} \mathrm{SO}_{4}$ in ethanol and subsequent heating. Silica gel 60 (230-400 mesh, Merck) was used for column chromatography. High-performance liquid chromatography (HPLC) was recorded with a Micromeritics liquid chromatograph equipped with a refractive index detector and a Micromeritics 730 injector.

The following solvents were distilled before use: dichloromethane $\left(\mathrm{CH}_{2} \mathrm{Cl}_{2}\right.$, from $\left.\mathrm{P}_{2} \mathrm{O}_{5}\right)$, acetonitrile (from $\left.\mathrm{P}_{2} \mathrm{O}_{5}\right)$, and pyridine (from $\mathrm{KOH}$ ). $N, N$-Dimethylformamide (DMF) was purified by sequential drying ${ }^{38}$ with $3-\AA$ molecular sieves and distillation.

Selective Benzoylation of Methyl $\alpha$-D-Glucopyranoside (1) with $N$-Benzoylimidazole. A suspension of $1(9.7 \mathrm{~g}, 0.05$ $\mathrm{mol})$ in dry acetonitrile $(400 \mathrm{~mL})$ was heated at reflux temperature, and $5-\mathrm{mL}$ portions of $N$-benzoylimidazole ${ }^{39}(31.0 \mathrm{~g}, 0.18 \mathrm{~mol})$ in acetonitrile $(50 \mathrm{~mL})$ were added. The addition was completed in about $8 \mathrm{~h}$, and the heating was continued for $24 \mathrm{~h}$ more. To the resulting clear, yellowish solution was added water $(3 \mathrm{~mL})$, and the mixture was stirred for $0.5 \mathrm{~h}$. The solvent was evaporated off at diminished pressure, and the residue was poured into ice-water $(400 \mathrm{~mL})$ to afford a syrupy precipitate, which was

(38) Burfield, D. R.; Smithers, R. H. J. Org. Chem. 1978, 43, 3966 (39) Staab, H. A. Angew. Chem., Int. Ed. Engl. 1962, 1, 351. 
washed with cold water $(200 \mathrm{~mL}$, twice) and dissolved in dichloromethane $(600 \mathrm{~mL})$. The solution was extracted with $5 \%$ $\mathrm{HCl}$, water, and $10 \%$ aqueous $\mathrm{NaHCO}_{3}$, dried $\left(\mathrm{MgSO}_{4}\right)$, and evaporated. A slightly yellow syrup was obtained (yield $28.60 \mathrm{~g}$ ), which showed at least three spots on TLC. A portion (7 g) of this mixture was tosylated as described below. Another sample (0.54 g) was analyzed by column chromatography (silica gel, $50 \mathrm{~g}$ ) with 19:1 toluene-ethyl acetate as eluant.

The fastest migrating component $\left(R_{f} 0.63\right)$ was the perbenzoylated derivative $2 \mathrm{a}(61 \mathrm{mg}, 10.6 \%$ yield from 1$)$, which after recrystallization from methanol gave $\mathrm{mp} 106-108^{\circ} \mathrm{C}$ (lit. ${ }^{40} \mathrm{mp}$ $105-108^{\circ} \mathrm{C}$ ).

The next fraction $\left(R_{f} 0.40\right)$ was methyl $2,4,6$-tri- $O$-benzoyl- $\alpha$ D-glucopyranoside (2b, $13 \mathrm{mg}, 2.7 \%$ yield), isolated as a colorless syrup: $[\alpha]^{25}{ }_{\mathrm{D}}+99^{\circ}\left(\right.$ lit. $\left.^{14}[\alpha]^{25}{ }_{\mathrm{D}}+98^{\circ}\right)$.

The main product, methyl 2,3,6-tri-O-benzoyl- $\alpha$-D-glucopyranoside (2c, $R_{f} 0.33$ ) was isolated $(0.34 \mathrm{~g}, 71.2 \%$ yield) from the next chromatographic fraction. After recrystallization from diisopropyl ether-hexane, it gave $\mathrm{mp} 125-126^{\circ} \mathrm{C}$ (lit. ${ }^{14} \mathrm{mp} 127-129$ $\left.{ }^{\circ} \mathrm{C}\right)$.

From the last fraction, the more polar component $\left(R_{f} 0.03\right)$ was obtained and identified as methyl 2,6-di-O-benzoyl- $\alpha$-D-glucopyranoside (2d, $50 \mathrm{mg}, 13.2 \%$ yield). Recrystallized from diisopropyl ether-hexane, it had $\mathrm{mp} 141-142^{\circ} \mathrm{C}$ (lit. ${ }^{14} \mathrm{mp} 140-142$ $\left.{ }^{\circ} \mathrm{C}\right)$.

Benzoylation after Stannylation of 1. The procedure of Ogawa and Matsui ${ }^{14 a}$ was followed. Starting from compound 1 (0.97 g, $5 \mathrm{mmol}$ ), methyl 2,3,6-tri- $O$-benzoyl- $\alpha$-D-glucopyranoside (2c) was obtained in $66.4 \%$ yield $(1.68 \mathrm{~g})$, after chromatographic purification.

Methyl 2,3,6-Tri- $O$-benzoyl-4- $O$-( $p$-tolylsulfonyl)- $\alpha$-Dglucopyranoside (2e). To a solution of the crude mixture (7.0 g) from benzoylation of 1 with $N$-benzoylimidazole in anhydrous pyridine a $0^{\circ} \mathrm{C}, p$-toluenesulfonyl chloride (tosyl chloride, 11.0 $\mathrm{g}, 0.058 \mathrm{~mol}$ ) was added slowly and with stirring. The mixture was kept for $48 \mathrm{~h}$ in the refrigerator and then poured into icewater, affording compound $2 \mathrm{e}$ as an amorphous solid, which crystallized upon addition of ethanol $(5.52 \mathrm{~g}, 68.3 \%$ yield from 1). Recrystallization from ethanol gave $\mathrm{mp} 139-140^{\circ} \mathrm{C},[\alpha]^{25}$ $+102^{\circ}$. Anal. Calcd for $\mathrm{C}_{35} \mathrm{H}_{32} \mathrm{O}_{11} \mathrm{~S}$ : C, 63.63; H, 4.88; $\mathrm{S}, 4.85$. Found: C, $63.91 ; \mathrm{H}, 5.04 ; \mathrm{S}, 5.19$.

Methyl 2,3,6-Tri- $O$-benzoyl-4- $O$-[(4-bromophenyl)sulfonyl]- $\alpha$-D-glucopyranoside (2f). To a solution of the crude product of partial benzoylation of $1(1.0 \mathrm{~g})$ in dry pyridine $(10$ $\mathrm{mL})$ was added 4 -bromobenzenesulfonyl chloride $(2.0 \mathrm{~g})$. The mixture was kept at room temperature for $48 \mathrm{~h}$, water $(2 \mathrm{~mL})$ was added, and the resulting mixture was then stirred for $0.5 \mathrm{~h}$. The solution was slowly poured into ice-water $(0.5 \mathrm{~L})$, affording an amorphous solid, which was filtered and dried in vacuum over $\mathrm{P}_{2} \mathrm{O}_{5}$. The solid $(0.84 \mathrm{~g}, 64 \%$ yield from 1$)$ did not crystallize. This material, essentialy pure as shown by its ${ }^{1} \mathrm{H}$ NMR spectrum and by TLC $\left(R_{f} 0.83\right)$, was employed for the next step of the synthesis.

Crystalline brosylate $2 \mathrm{f}$ was obtained by reaction of chromatographically purified tribenzoate $2 \mathrm{c}(0.103 \mathrm{~g}, 0.20 \mathrm{mmol})$ and 4-bromobenzenesulfonyl chloride $(0.08 \mathrm{~g}, 0.31 \mathrm{mmol})$, in pyridine ( $3 \mathrm{~mL}$ ). The resulting amorphous solid crystallized from $\mathrm{CH}_{2} \mathrm{Cl}_{2}$-hexane, affording $0.125 \mathrm{~g}$ (85\% yield) of compound $2 \mathrm{f}$ : mp $160-161^{\circ} \mathrm{C} ;[\alpha]^{25}{ }_{\mathrm{D}}+76.2^{\circ}$. Anal. Calcd for $\mathrm{C}_{34} \mathrm{H}_{29} \mathrm{BrO}_{11} \mathrm{~S}$ : C, 56.28; H, 4.03. Found: C, 56.63; H, 4.04.

Methyl 2,3,6-Tri- $O$-benzoyl-4-deoxy-4-thiocyano- $\alpha$-Dgalactopyranoside (3). (a) Starting from Tosylate 2e. To a solution of the 4-O-tosyl derivative $(2 \mathrm{e} ; 3.0 \mathrm{~g}, 4.66 \mathrm{mmol})$ in dry DMF $(25 \mathrm{~mL})$ was added potassium thiocyanate $(3.12 \mathrm{~g}, 32.1$ $\mathrm{mmol}$ ). The mixture was heated at $110^{\circ} \mathrm{C}$, with stirring, under a nitrogen atmosphere for $48 \mathrm{~h}$, and then it was poured into ice-water $(500 \mathrm{~mL})$ and extracted with dichloromethane $(3 \times 200$ $\mathrm{mL})$. The organic extract was washed with water, dried $\left(\mathrm{MgSO}_{4}\right)$, and evaporated. The residue was chromatographed on a silica gel column using 99:1 toluene-ethyl acetate as eluent. Fractions containing the product having $R_{f} 0.58$ were pooled and evaporated, affording $1.80 \mathrm{~g}$ (72.5\% yield) of compound $3:[\alpha]^{25}+50^{\circ}$. Anal.

(40) Ness, R. K.; Fletcher, H. G., Jr.; Hudson, C. S. J. Am. Chem. Soc. $1950,72,2200$.
Calcd for $\mathrm{C}_{29} \mathrm{H}_{25} \mathrm{NO}_{8} \mathrm{~S}$ : $\mathrm{C}, 63.61 ; \mathrm{H}, 4.60 ; \mathrm{N}, 2.56$. Found: $\mathrm{C}, 63.56$; $\mathrm{H}, 4.32 ; \mathrm{N}, 2.65$.

The above reaction was performed in the presence of 18-crown- 6 [18-crown-6 (1,4,7,10,13,16-hexaoxacyclooctadecane)]. To a solution of compound $2 \mathrm{e}(2.0 \mathrm{~g}, 3.03 \mathrm{mmol})$ in DMF $(15 \mathrm{~mL})$ were added potassium thiocyanate $(2.10 \mathrm{~g}, 21.4 \mathrm{mmol})$ and 18-crown-6 (66 mg, $0.25 \mathrm{mmol}$ ). The mixture was stirred at $110^{\circ} \mathrm{C}$ under nitrogen for $17 \mathrm{~h}$ and then processed as before, affording after column chromatography $1.03 \mathrm{~g}$ (62\% yield) of compound 3 .

(b) Starting from the Brosylate 2f. The crude product $(0.57$ g) obtained by brosylation of the mixture of benzoylation of 1 was dissolved in DMF ( $4 \mathrm{~mL})$, and potassium thiocyanate $(0.52$ $\mathrm{g}, 5.35 \mathrm{mmol}$ ) was added. The solution was stirred at $110^{\circ} \mathrm{C}$, under nitrogen for $17 \mathrm{~h}$, and then processed as described in a. After chromatographic purification, $0.36 \mathrm{~g}$ ( $54 \%$ yield from 1 ) of the thiocyanate derivative 3 was obtained.

Methyl 4-S-Acetyl-2,3,6-tri- $O$-benzoyl-4-thio- $\alpha$-Dgalactopyranoside (4a). A suspension of compound $3(1.5 \mathrm{~g}$, $2.74 \mathrm{mmol}$ ) and powdered zinc $(1.5 \mathrm{~g})$ in glacial acetic acid (15 $\mathrm{mL}$ ) and acetic anhydride $(15 \mathrm{~mL})$ was heated for $18 \mathrm{~h}$ under reflux. The mixture was then poured into water $(50 \mathrm{~mL})$ and extracted with $\mathrm{CH}_{2} \mathrm{Cl}_{2}(3 \times 50 \mathrm{~mL})$. The extract was washed with saturated aqueous sodium hydrogen carbonate $(2 \times 50 \mathrm{~mL})$ and water $(50 \mathrm{~mL})$, dried $\left(\mathrm{MgSO}_{4}\right)$, and evaporated. The residue was purified by column chromatography on silica gel, with 19:1 toluene-ethyl acetate. Fractions containing the product having $R_{f}$ 0.58 were pooled and evaporated to give $0.72 \mathrm{~g} \mathrm{(46.5 \%} \mathrm{yield)} \mathrm{of}$ compound 4a: $[\alpha]^{25}{ }_{\mathrm{D}}+58^{\circ}$. Anal. Calcd for $\mathrm{C}_{30} \mathrm{H}_{28} \mathrm{O}_{9} \mathrm{~S}: \mathrm{C}, 63.82$; $\mathrm{H}, 5.00 ; \mathrm{S}, 5.68$. Found: C, 63.65; H, 5.28; S, 5.69.

Methyl 2,3,6-Tri- $O$-benzoyl-4-thio- $\alpha$-D-galactopyranoside (4b). A suspension of crude thiocyanate $3(1.50 \mathrm{~g})$, obtained by potassium thiocyanate substitution from $2 \mathrm{e}(2.00 \mathrm{~g}, 3.03 \mathrm{mmol})$, and powdered zinc $(1.7 \mathrm{~g})$ in glacial acetic acid $(50 \mathrm{~mL})$ was heated under reflux for $24 \mathrm{~h}$. The mixture was filtered, and the filtrate was slowly poured into cold water, affording a chromatographically homogeneous solid $\left(R_{f} 0.65\right)$, which crystallized from ethanol to give $1.10 \mathrm{~g}(69.5 \%$ yield from $2 \mathrm{e})$ of compound $4 \mathrm{~b}: \mathrm{mp}$ 161-163 ${ }^{\circ} \mathrm{C} ;[\alpha]^{25} \mathrm{D}+111^{\circ}$; IR (Nujol) $2560 \mathrm{~cm}^{-1}$ (SH). Anal. Calcd for $\mathrm{C}_{28} \mathrm{H}_{26} \mathrm{O}_{8} \mathrm{~S}: \mathrm{C}, 64.36 ; \mathrm{H}, 5.01 ; \mathrm{S}, 6.14$. Found: $\mathrm{C}, 64.63 ; \mathrm{H}, 5.30$; $\mathrm{S}, 6.39$.

Methyl 4-Thio- $\alpha$-D-galactopyranoside (5). Compound $4 b$ $(0.59 \mathrm{~g}, 1.13 \mathrm{mmol})$ was suspended in a solution prepared by dissolving sodium $(0.12 \mathrm{~g}, 5.22 \mathrm{mmol})$ in methanol $(50 \mathrm{~mL})$. After $2 \mathrm{~h}$ at room temperature when no starting material was detected by TLC, the solution was neutralized with Dowex $50 \mathrm{~W}\left(\mathrm{H}^{+}\right)$, filtered, and evaporated. The residue was evaporated twice with $5-\mathrm{mL}$ portions of water, to remove methyl benzoate, affording 0.22 g ( $93 \%$ yield) of a syrup, homogeneous by TLC $\left(R_{f} 0.69,2: 1: 1\right.$ butanol-acetic acid-water). The syrup crystallized on storage, and crude crystals were recrystallized from ethyl acetate to give analytically pure compound $\mathbf{5}: \mathrm{mp} 116-118^{\circ} \mathrm{C} ;[\alpha]^{25} \mathrm{D}+232^{\circ}(\mathrm{c}$ 0.7 , methanol); IR (Nujol) $3100-3550(\mathrm{OH}), 2550 \mathrm{~cm}^{-1}$ (SH). Anal. Calcd for $\mathrm{C}_{7} \mathrm{H}_{14} \mathrm{O}_{5} \mathrm{~S}$ : C, 39.99; H, 6.71; S, 15.25. Found: C, 39.86; $\mathrm{H}, 6.71 ; \mathrm{S}, 15.28$.

The title compound (5) was also obtained by reaction of the thiocyano derivative 3 with sodium methoxide. A suspension of $3(0.45 \mathrm{~g}, 0.82 \mathrm{mmol})$ in a $0.1 \mathrm{~N}$ methanolic solution of sodium methoxide $(50 \mathrm{~mL})$ was stirred for $5 \mathrm{~h}$ at room temperature. The reaction mixture was treated as described above to give $0.15 \mathrm{~g}$ of a syrup, which was purified by column chromatography (ethyl acetate), affording $82 \mathrm{mg}$ ( $47 \%$ yield) of compound 5 .

$1,2,3,5,6$-Penta- $O$-acetyl-4-thio- $\alpha$-D-galactofuranose (10), $1,2,3,5,6$-Penta- $O$-acetyl-4-thio- $\beta$-D-galactofuranose (11), and 1,2,3,6-Tetra- $O$-acetyl-4- $S$-acetyl-4-thio- $\alpha$-D-galactopyranose (12). Crystalline methyl 4-thio- $\alpha$-D-galactopyranoside $(5 ; 50 \mathrm{mg}$, $0.24 \mathrm{mmol}$ ) was dissolved at $0^{\circ} \mathrm{C}$ in a solution of glacial acetic acid $(5 \mathrm{~mL})$, acetic anhydride $(5 \mathrm{~mL})$, and sulfuric acid $(0.3 \mathrm{~mL})$. The mixture was kept at $4{ }^{\circ} \mathrm{C}$ for $48 \mathrm{~h}$, and sodium acetate $(1.7$ g) was added. After $0.5 \mathrm{~h}$ of stirring at room temperature, the solution was poured into ice-water $(0.1 \mathrm{~L})$ and extracted with $\mathrm{CH}_{2} \mathrm{Cl}_{2}(3 \times 0.1 \mathrm{~L})$. The organic layer was washed with saturated aqueous sodium hydrogen carbonate, dried $\left(\mathrm{MgSO}_{4}\right)$, and evaporated. The residue, which showed two spots by TLC $\left(R_{f} 0.49\right.$ and 0.39 in 7:3 toluene-ethyl acetate), was chromatographed on silica gel with 9:1 toluene-ethyl acetate. Fractions containing the lower migrating component $\left(R_{f} 0.39\right)$ were pooled and evaporated, 
affording $44 \mathrm{mg}$ ( $45 \%$ yield) of a syrup, which crystallized on storage. Recrystallization from ether gave pure compound 10: mp $96-97^{\circ} \mathrm{C} ;[\alpha]^{25} \mathrm{D}+98.4^{\circ} ;$ IR (neat) 1750 (carbonyl of $\mathrm{CH}_{3} \mathrm{COO}$ ) MS $m / z$ (relative intensity) $406\left(\mathrm{M}^{+}\right), 347(2), 346(5), 286(4)$, 245 (4), 244 (10), 226 (81), 186 (50), 185 (59), 184 (47), 159 (10) 144 (32), 143 (72), 142 (100). Anal. Calcd for $\mathrm{C}_{16} \mathrm{H}_{22} \mathrm{O}_{10} \mathrm{~S} \mathrm{C}, 47.29$; $\mathrm{H}, 5.46 ; \mathrm{S}, 7.89$. Found: C, 47.55; H, 5.66; S, 7.93.

Evaporation of the fractions having $R_{f} 0.49$ gave $42 \mathrm{mg}$ of a syrup. The ${ }^{1} \mathrm{H}$ NMR spectrum of this material showed it to contain two main components. The mixture was separated by HPLC (Altech R-Sil C-18 column $(10 \mu \mathrm{m}), 50 \times 1 \mathrm{~cm}$, at a flow rate of $1.2 \mathrm{~mL} / \mathrm{min}$ ) with $1: 1$ acetone-water. The fractions having $t_{\mathrm{R}} 16.1 \mathrm{~min}$ were evaporated, affording $24 \mathrm{mg}$ ( $25 \%$ yield) of compound 11 . The other fraction $\left(t_{\mathrm{R}} 18.0 \mathrm{~min}\right)$ gave, upon evaporation, $12 \mathrm{mg}$ (12\% yield) of compound 12 .

For 11: $[\alpha]^{25}-123^{\circ}(c 0.7)$; IR (neat) $1750 \mathrm{~cm}^{-1}$ (carbonyl of $\mathrm{CH}_{3} \mathrm{COO}$ ); $\mathrm{MS} m / z$ (relative intensity) $406\left(\mathrm{M}^{+}\right), 347(6), 346(8)$ $304(2), 286$ (5), 261 (3), 245 (6), 244 (52), 226 (74), 186 (76), 185 (49), 184 (52), 159 (53), 145 (49), 144 (69), 143 (65), 142 (100). Anal. Calcd for $\mathrm{C}_{16} \mathrm{H}_{22} \mathrm{O}_{10} \mathrm{~S}$ : C, $47.29 ; \mathrm{H}, 5.46 ; \mathrm{S}, 7.89$. Found: C, 47.43; $\mathrm{H}, 5.61 ; \mathrm{S}, 7.72$.

For 12: $[\alpha]^{25}+39^{\circ}$ (c 0.7); IR (neat) 1700 (carbonyl of $\mathrm{CH}_{3} \mathrm{COS}$ ), $1750 \mathrm{~cm}^{-1}$ (carbonyl of $\mathrm{CH}_{3} \mathrm{COO}$ ); $\mathrm{MS} \mathrm{m} / z$ (relative intensity) $406\left(\mathrm{M}^{+}\right), 345(4), 304(4), 258(4), 245(10), 244(44)$, $243(66), 226(7), 185(46), 184(68), 43(100)$. Anal. Calcd for $\mathrm{C}_{16} \mathrm{H}_{22} \mathrm{O}_{10} \mathrm{~S}$ : C, 47.29; $\mathrm{H}, 5.46 ; \mathrm{S}, 7.89$. Found: $\mathrm{C}, 47.39 ; \mathrm{H}, 5.75$ $\mathrm{S}, 7.67$.
The acetolysis reaction performed on the crude product $(0.3-0.5$ g) of alkaline methanolysis of 3 gave compounds 10, 11, and 12 in $50-55 \%$ overall yield.

4-Thio-D-galactose (15). Compound 10 ( $81 \mathrm{mg}, 0.2 \mathrm{mmol}$ ) was added to a solution prepared by dissolving sodium $(20 \mathrm{mg})$ in methanol $(10 \mathrm{~mL})$, and the mixture was stirred, under nitrogen, for $1 \mathrm{~h}$ at $0^{\circ} \mathrm{C}$. The solution was neutralized with Dowex $50 \mathrm{~W}$ $\left(\mathrm{H}^{+}\right)$, filtered, and evaporated. The residue was dissolved in water and extracted with ether. The aqueous solution was freeze-dried, affording $37 \mathrm{mg}$ (95\% yield) of 4-thio-D-galactose (15): $[\alpha]^{25}$ $+13.5^{\circ}$ (c 1, water, $\left.10 \mathrm{~min}\right) \rightarrow+12.8^{\circ}(12 \mathrm{~h}) ;{ }^{13} \mathrm{C}$ NMR $(1: 1$ $\left.\mathrm{D}_{2} \mathrm{O}-\mathrm{H}_{2} \mathrm{O}\right) \delta 84.1(\mathrm{C}-1 \beta), 79.8(\mathrm{C}-1 \alpha, \mathrm{C}-2 \beta), 76.2(\times 2), 76.0,73.1$, $71.6,65.9(\times 2), 51.5(\mathrm{C}-4 \beta), 50.0(\mathrm{C}-4 \alpha)$. Anal. Calcd for $\mathrm{C}_{6} \mathrm{H}_{12} \mathrm{O}_{5} \mathrm{~S}$ C, 36.73; H, 6.16. Found: C, 36.77; H, 6.26.

Acknowledgment. We are indebted to CONICET (Consejo Nacional de Investigaciones Cientificas y Técnicas), the University of Buenos Aires, and UNDP/ World Bank/WHO Special Programme for Research and Training in Tropical Diseases for financial support and to UMYMFOR (CONICET-FCEN, Buenos Aires) for the microanalyses and MS.

Registry No. 1, 97-30-3; 2a, 32849-03-9; 2b, 118918-78-8; 2c 57784-06-2; 2d, 26927-44-6; 2e, 19467-77-7; 2f, 57784-05-1; 3, 20272-21-3; 4a, 118868-79-4; 4b, 118868-80-7; 5, 118868-81-8; 10 , $118918-79-9 ; 11,118918-80-2 ; 12,118918-81-3 ; 15,118868-82-9$.

\title{
Palladium(0)-Based Approach to Functionalized C-Glycopyranosides
}

\author{
Mohamed Brakta, Paul Lhoste, and Denis Sinou* \\ Laboratoire de Synthèse Asymétrique, UA du CNRS 463, Universitê Claude Bernard Lyon I, 43, boulevard du \\ 11 Novembre 1918, 69622-Villeurbanne Cedex, France
}

Received August 9, 1988

\begin{abstract}
Phenyl 4,6-di- $O$-benzyl-2,3-dideoxy-D-erythro-hex-2-enopyranoside $4 \alpha$ or $5 \beta$ reacts with ethyl malonate, acetylacetone, methyl acetylacetate, ethyl nitroacetate, and ethyl nitromalonate under neutral conditions in the presence of $\mathrm{Pd}(0)$ to give regiospecifically and stereoselectively the $\alpha$ or $\beta \mathrm{C}$-glycopyranoside in excellent yields. ${ }^{1} \mathrm{H}$ and ${ }^{13} \mathrm{C}$ NMR parameters have been used for assigning the $\alpha$ or $\beta$ configuration for a given pair of these anomers.
\end{abstract}

\section{Introduction}

Carbon-carbon bond-forming reactions at the anomeric position of carbohydrates have attracted considerable attention during the last few years in connection with the synthesis of chiral building blocks and naturally occurring products. ${ }^{1}$ Current examples include applications of the enolate ester Claisen rearrangement, ${ }^{2}$ Lewis acid generation of the oxocarbenium ion followed by nucleophilic addition, ${ }^{3}$

(1) Reviews: (a) Hanessian, S.; Pernet, A. G. Adv. Carbohydr. Chem Biochem. 1976, 33, 111. (b) Hanessian, S. Total Synthesis of Natura Products: The Chiron Approach; Pergamon: Oxford, 1983. (c) Inch, T. D. Tetrahedron 1984, 40, 3161. (d) Hacksell, U.; Daves, G. D., Jr. Prog. Med. Chem. 1985, 22,1. (e) Buchanan, J. G. Prog. Chem. Org. Natl. Prod. $1983,44,243$.

(2) (a) Ireland, R. E.; Vevert, J. P. Can. J. Chem. 1981, 59, 572. (b) Ireland, R. E.: Wutz, P. G. M.; Ernst, B. J. Am. Chem. Soc. 1981, 103 3205. (c) Ireland, R. E. Daub, J P.J. Org. Chem 1981, 46, 479. (d) Ireland, R. E.; Thaisrivongs, S.; Wilcox, C. S. J. Am. Chem. Soc. 1980 , 102, 1155. (e) Ireland, R. E.; Wilcox, C. S.; Thaisrivongs, S.; Varnier, N. R. Can. J. Chem. 1979, 57, 1743. (f) Ireland, R. E; Andersen, R. C.; Badoub, R.; Fitzsimmons, B. J.; McGarvey, G.; Thaisrivongs, S.; Wilcox, C. S. J. Am. Chem. Soc. 1983, 105, 1988. (g) Ireland, R. E.; Norbeck, D. W.; Mandel, G. S.; Mandel, N. S. J. Am. Chem. Soc. 1985, 107, 3285. (h) Curran, D. P.; Suh, Y. G. Carbohydr. Res. 1987, 171, 161. glycosyllithium additions, ${ }^{4}$ nucleophilic displacement on glycal methanesulfonates, ${ }^{5}$ allylstannane coupling with

(3) (a) Grynkiewicz G. Be Miller J. N. J. Carbohydr. Chem. 1982, 1 121. (b) Herscovici, J Muleka K Antonakis, K Tetrahedron Lett. 1984, 25, 5653. (c) Herscovici, J.; Delatre, S.; Antonakis, K. J. Org. Chem. 1987, 52, 5691. (d) Lewis, M. D.; Cha, J. K.; Kishi, Y. J. Am. Chem. Soc. 1982, 104, 4976. (e) Kozikowski, A. P. Sorgi, K. L. Tetrahedron Lett. 1984, 25, 2085. (f) Cupps, T. L.; Wise, D. S.; Towsend, L. B. J. Org. Chem. 1982, 47, 5115. (g) Steward, A. D.; Williams, R. M. J. Am. Chem. Soc. 1985, 107, 4289. (h) Danishefsky, S. J.; Kerwin, J. F. J. Org. Chem. 1982, 47, 3803. (i) Danishefsky, S. J.; Dewinno, S.; Lartey, P. J. Am. Chem. Soc 1987, 109, 2082. (j) Posner, G. H.; Haines, S. R. Tetrahedron Lett. 1985 26, 1823. (k) Schmidt, R. R.; Hoffman, H. Tetrahedron Lett. 1982, 23, 409. (1) Nicolaou, K. C.; Dolle, R. E.; Chucholowski, A.; Randall, J. L. J. Chem. Soc., Chem. Commun. 1984, 1153. (m) Hanessian, S.; Sato, K. Liak, T. J.; Danh, N.; Dixit, D.; Cheney, B. V. J. Am. Chem. Soc. 1984 106, 6114. (n) Ichikawa, Y.; Isobe, M.; Konobe, M.; Goto, T. Carbohydr. Res. 1987, 171, 193. (o) Hosomi, A.; Sakata, Y.; Sakurai, H. Carbohydr. Res. 1987, 171, 223.

(4) (a) Lesimple, P. Beau, J. M. Sinay, P. J. Chem. Soc. Chem. Commun. 1985, 894. (b) Beau, J. M.; Allory, L. M.; Sinay, P. J. Chem. Soc., Chem. Commun. 1984, 355. (c) Beau, J. M.; Sinay, P. Tetrahedron Lett. 1985, 26, 6185. (d) Beau, J. M.; Sinay, P. Tetrahedron Lett. 1985 26, 6189. (e) Beau, J. M. Sinay, P. Tetrahedron Lett. 1985, 26, 6193. (f) Lesimple, P.; Beau, J. M.; Sinay, P. Carbohydr. Res. 1987, 171, 289. (g) Valverde, S.; Garcia-Ochoa, S.; Martin-Lomas, M. J. Chem. Soc., Chem. Commun. 1987, 383 